\title{
IMPLEMENTASI SIKAP KESALEHAN SPIRITUAL DAN SOSIAL PADA MATA KULIAH AL-ISLAM DAN KEMUHAMMADIYAHAN
}

\author{
Milana Abdillah Subarkah*, E. Kurniyati ** \\ *milana.abdillah@umt.ac.id,** etykurniyati@umt.ac.id \\ * Dosen Pendidikan Agama Islam, Universitas Muhammadiyah Tangerang \\ **Dosen Magister Pendidikan Agama Islam, Universitas Muhammadiyah Tangerang
}

\begin{abstract}
Muhammadiyah higher education is a charitable business that has been successfully developed by Muhammadiyah organizations, as a means of preaching Islam to all Indonesian people. With the holding of Al-Islam and Muhammadiyah courses in each PTM, it is hoped that this can realize Muhammadiyah's ideals, namely, upholding and realizing Islam so that the real Islamic community can be realized. This study tries to provide an overview of the spiritual and social piety attitudes of students who have completed AIK courses by empowering the poor. This research is a qualitative research, researchers obtain data from literature studies of book sources, journals, scientific papers, as well as the results of interviews and documentation of empowerment activities for the poor. The results of research on the implementation of spiritual and social piety in Al-Islam and Muhammadiyah subjects include fostering an attitude of being able to read the Koran and its translation, fostering the spirit of practicing the Koran in everyday life, and fostering empathy or caring to others.
\end{abstract}

Keywords: Spiritual, Social, Islamic, Muhammadiyah

\section{A. PENDAHULUAN}

Islam mengajarkan pemeluknya untuk selalu meningkatkan kualitas keilmuan dan pengetahuan. Baik tua atau muda, pria atau wanita, miskin atau kaya mendapatkan porsi sama dalam pandangan Islam dalam kewajiban untuk menuntut ilmu (pendidikan). Bukan hanya pengetahuan yang terkait urusan akhirat saja yang ditekankan oleh Islam, melainkan pengetahuan yang terkait dengan urusan dunia juga harus kuasai. Karena dalam pemehaman ajaran Islam tidak mungkin manusia mencapai kebahagiaan dihari kemudian tanpa melalui jalan kehidupan dunia ini.

Islam menghendaki pengetahuan yang benar-benar dapat membantu mencapai kemakmuran dan kesejahteraan hidup bagi umat manusia. Yaitu pengetahuan terkait urusan dunia dan akhirat, yang dapat menjamin kemakmuran dan kesejahteraan hidup manusia di dunia dan akhirat. Pengetahuan duniawi adalah berbagai pengetahuan yang berhubungan dengan urusan kehidupan manusia di dunia ini. Baik pengetahuan modern maupun pengetahuan klasik. Atau lumrahnya disebut dengan pengetahuan umum.

Dari pengertian di atas dapat dipahami bahwa Islam sebagai ajaran agama yang dibawa oleh Nabi Muhammad Saw sebagai utusan yang terakhir berfungsi sebagai petunjuk bagi kehidupan umat manusia. Islam memiliki nilai ajaran universal yang sesuai dengan kebutuhan manusia. Karena Islam memiliki ajaran universal, maka ia memiliki bentuk ajaran yang lebih sempurna dibandingkan dengan ajaran sebelumnya. Kesempurnaan ajaran Islam terlihat pada keselarasan nilai-nilai ajarannya dengan fitrah manusia, dalam arti selaras dengan kejadian alamiah manusia (Rusmin, 2017).

Pada tataran Pendidikan, Islam memiliki tujuan yang menginginkan umatnya untuk meningkatkan kualitas kesalehan spiritual dan sosial, yaitu 
kepribadian seseorang yang menbuatnya menjadi "insan kamil" artinya manusia yang utuh rohani dan jasmani, dapat hidup dan berkembang secara wajar dan normal karena takwanya kepada Allah Swt. Ini mengandung arti bahwa pendidikan Islam itu diharapkan menghasilkan manusia yang berguna bagi dirinya dan masyarakatnya serta senang dan gemar mengamalkan dan mengembangkan ajaran Islam dalam berhubungan dengan Allah dan dengan manusia sesamanya (Hawi, 2013).

Sementara itu, Pada konsep Pendidikan yang ada pada lembaga Pendidikan Muhammadiyah yang mengharapkan para peserta didiknya memiliki kemampuan ganda yakni mengembangkan potensi pengetahuan umum dan disisi lain mengembangkan wawasan keagamaan dalam kehidupan sehari-hari. Dengan integrasi keilmuan tersebut pada perguruan persyarikan Muhammadiyah dalam waktu yang bersamaan ingin menghasilkan lulusan yang intelektual sekaligus yang ulama serta ulama yang intelektual, hal ini dilakukan pada semua jenjang Pendidikan mulai di tingkat dasar samapai pada perguruan tinggi.

Inilah yang membedakan perguruan tinggi Muhammadiyah dengan perguruan tinggi di luar Muhammadiyah baik perguruan tinggi negeri maupun swasta adalah, bahwa di perguruan tinggi Muhammadiyah muatan Pendidikan Islam pada program studi di luar program studi Pendidikan Agama Islam atau program studi umum bisa lebih dari 10 sks terdiri dari 5 semester. Sementara perguruan tinggi lain hanya mendapat 4 sks yang terdiri dari 2 semester saja.

Muhammadiyah sebagai organisasi kemasyarakatan Islam di Indonesia yang usianya sudah mencapai 108 tahun telah banyak berkontribusi untuk bangsa dan negara Indonesia terutama pada bidang Pendidikan. Bukti bahwa Muhammadiyah telah berkiprah pada dunia Pendidikan Muhammadiyah memiliki amal usaha dibidang Pendidikan yang sangat banyak dan tersebar di seluruh Indonesia, mulai dari Lembaga Pendidikan usia dini hingga perguruan tinggi. Karena bagi Muhammadiyah hanya melalui aktivitas Pendidikan sajalah dakwah Islam bisa tersampaikan dengan baik secara efektif dan efisien kepada seluruh masyarakat Indonesia. Hal ini sebagaimana maksud dan tujuan dari persyarikatan Muhammadiyah yang tertuang pada Muqaddimah Anggaran dasar Muhammadiyah yakni, "Menegakkan dan menjunjung tinggi perintah agama Islam, sehingga terwujudnya masyarakat Islam yang sebenar-benarnya".

Dengan demikian, Muhammadiyah adalah organisi terbesar di Indonesia dengan jumlah amal usaha dalam bidang pendidikan yang banyak. Banyaknya perguraun Muhammadiyah ini menjadi peluang sekaligus tantangan untuk mengelolanya. Pendidikan yang sudah berjalan ini perlu dikuatkan kembali fungsinya. Pendidikan Muhammadiyah memiliki empat dasar semangat yaitu, pendidikan, pelayanan, dakwah, dan perkaderan. Empat semangat itu yang tidak boleh padam dalam mensyiarkan Islam kepada masyarakat. Pendidikan sebagai pelayanan dan juga tidak mengesampingkan fungsi dakwah dan perkaderan. Maka Pendidikan yang terdapat di perguruan tinggi Muhammadiyah yang dikenal dengan istilah Al-Islam dan Kemuhammadiyahan atau AIK diharapkan mampu memberikan pengalaman yang memberikan kesan dan makna positif kepada para mahasiswanya, yaitu menhadirkan keshalehan spiritual dan sosial dimanapun dan kapanpun mereka berada.

Eksistensi mata kuliah AIK sangat signifikan dalam membentuk mahasiswa di perguruan tinggi Muhammadiyah yang profesional, intelektual, dan personal religious yang mampu berkompetisi di era globalisasi. Harapan tersebut didasari pada tujuan umum mata kuliah AIK yang akan dicapai, yakni terbentuknya manusia pembelajar yang bertakwa, berakhlak mulia, berkemajuan dan unggul dalam IPTEKS sebagai perwujudan tajdid dakwah amar ma'ruf nahi munkar (Syamsu, 2019). 
Oleh karenanya memalui tulisan ini penulis akan memaparkan urgensi mata kuliah AIK sekaligus impelementasi spiritual dan sosial bagi mahasiswa selama mengikuti pembelajaran AIK di semester III.

\section{B. METODE PENELITIAAN}

Sebagaimana Sukmadinata dalam Milana dalam melakukan penelitian ini menggunakan penelitian deskriptif. Yaitu mengamati berbagai kejadian yang terjadi. Penelitian ini akan mendeskripsikan pelaksanaan pelaksanaan pembelajaran mata kuliah AIK di Semester III pada perguruan tinggi Universitas Muhammadiyah Tangerang dalam upaya menanamkan nilai keshalehan spiritual dan sosial (Milana et.al, 2020). Adapun prosedur yang dilakukan adalah dengan mencermati aktivitas pembelajaran AIK serta menganalisis perkuliahan apakah pembelajaran mata kuliah AIK mampu menumbuhkan implementasi sikap kesalehan spiritual dan sosial mahasiswa dalam keseharian. Kemudian, melakukan desain deskriptif survei, digunakan untuk menguji hipotesis. Pengumpulan data dengan teknik observasi, dokumentasi, dan wawancara. Teknik obsevasi dilakukan untuk mengetahui aktivitas pembelajaran mata kuliah AIK pada semester III Program Studi Akuntansi FEB Universitas Muhammadiyah Tangerang.

Selain itu, pembagian angket untuk mengatahui pelaksanaan mata kuliah AIK yang ditunjukkan dengan indikatorindikator yang relevan. Wawancara, dilakukan kepada dosen AIK untuk mengetahui sikap implementasi keshalehan spiritual dan sosial pembelajaran AIK, kendala yang dihadapi dan pemecahan terkait kendala dalam implementasi evaluasi pembelajaran di kelas. Dokumentasi, dilakukan untuk mendapatkan data atau peristiwa yang terjadi pada saat proses pembelajaran berlangsung (Milana et.al, 2020).

\section{HASIL DAN PEMBAHASAN}

Aktivitas Pendidikan Islam dan Kemuhammadiyahan di peruguruan tinggi Muhammadiyah adalah penyiapan lingkungan yang mengharapkan seseorang peserta didik tumbuh sebagai insan yang menyadari kehadiran Allah Swt sebagai Robb dan menguasai ilmu pengetahuan, teknologi dan seni (IPTEKS). Dengan kesadaran sesalehan spiritual makrifat (iman/ tauhid) dan pengusaan IPTEKS, seseorang peserta didik mampu memenuhi kebutuhan hidupnya secara mandiri, peduli pada permasalahan sosial yakni kepada masyarakat yang menderita akibat kebodohan dan kemiskinan, senantiasa menyebarluaskan kemakrufan, mencegah kemungkaran bagi pemuliaan kemanusiaan dalam kerangka kehidupan bersama yang ramah lingkungan dalam sebuah bangsa dan tata pergaulan dunia yang adil, beradab dan sejahtera sebagai ibadah kepada Allah (Muhammadiyah, 2013).

Pendidikan Islam dan

Kemuhammadiyahan (AIK) merupakan pendidikan Islam modern yang mengintegrasikan keilmuan agama dengan kehidupan dan antara iman dan kemajuan yang holistik. Dari rahim pendidikan Islam dan Kemuhammadiyahan diharapkan lahir generasi muslim terpelajar yang kuat iman dan kepribadiannya, sekaligus mampu menghadapi dan menjawab tantangan zaman. Inilah pendidikan Islam yang berkemajuan.

Sementara itu, IPTEKS adalah hasil pemikiran rasional yang holistik dan komprehensif atas realitas alam semesta (ayat kauniyah) dan atas wahyu dan sunnah (ayat qauliyah) yang merupakan satu kesatuan integral melalui kegiatan penelitian dan pengembangan yang terus menerus diperbarui bagi kemuliyaan kemanusiaan dalam alam kehidupan yang lestari. Penguasaan IPTEKS merupakan langkah awal tumbuhnya kesadaran makrifat (iman/ tauhid), sehingga pemikiran rasional adalah awal dari kesadaran spiritual makrifat ketuhanan. Pengabdian ibadah kepada Allah meliputi ibadah yang terangkum dalam rukun Islam, penelitian dan pengembangan IPTEKS, penataan lingkungan hidup yang lestari 
berkelanjutan dalam kehidupan bersama yang beradab, berkeadilan, dan sejahtera, serta pembebasan setiap orang dari penderitaan akibat kebodohan dan kemiskinan.

Pendidikan AIK yang ditrasnformasikan menjadi mata kuliah di PTM memiliki posisi strategis, menjadi ruh penggerak, dan misi utama penyelenggaraan PTM. Mata kuliah AIK juga menjadi kekuatan PTM karena dapat menjadi basis kekuatan spiritual, sosial, moral dan intelektual serta daya gerak bagi seluruh civitas akademika. Keberhasilan mata kuliah AIK menjadi salah satu indikator ketercapaian misi penyelenggaraan dan pengelolaan PTM. Peningkatan mutu proses dan hasil (outcome) pendidikan AIK harus dilaksanakan terus menerus dan tersistem.

Mata kuliah AIK memandang ajaran Islam sebagai petunjuk jalan yang lurus, modal sosial, jalan menuju Tuhan, dan jalan kebahagiaan hidup di dunia dan akhirat, yakni jalan yang tepat untuk mengingkatkan kesalehan spiritual dan sosial. Pengajaran agama Islam sebagai ilmu yaitu ilmu-ilmu tentang keislaman baik yang bersifat normatif maupun historis sosiologis lebih tepat diberikan pada mahasiswa yang memang mengambil spesialisasi di bidang ilmu-ilmu agama namun dalam waktu yang bersamaan sangat relevan juga bagi mahasiswa yang bidang keahlianya di luar program studi agama Islam.

Oleh karennya, Tujuan mata kuliah AIK pada setiap program studi di PTM untuk membentuk insan berkarakter dan insan terpelajar serta memiliki integritas dan kesadaran etis. Dalam Al-Qur'an surat al-Qashash ayat 77 Allah berfirman yang artinya: “...dan berbuat baiklah sebagaimana Allah telah berbuat baik kepadaти...". Bagi insan terpelajar, beramal shaleh baik yang bersifat ritual maupun sosial seharusnya tidak didasarkan pada faktor dari luar dirinya (ganjaran dan ancaman), melainkan sebagai bentuk panggilan etis, beramal shaleh sebagai manifestasi rasa terima kasih kepada Allah dan sesama. Pendidikan AIK untuk membentuk manusia berkemajuan, berjiwa pengasih, dan penuh kasih kepada sesama (philantropis) (Muhammadiyah, 2013).

Kemudian, sebagaimana penjelasan dari pedoman Pendidikan AIK yang telah dirumuskan oleh Majelis Dikti Pimpinan Pusat Muhammadiyah. Terdapat beberapa materi pokok yang menjadi fokus penanaman nilai Pendidikan Islam dan Kemuhammadiyahan mulai dari materi tentang aqidah, akhlak, sumber ajaran Islam (Al-Qur'an dan Hadist), fiqih, dan Kemuhammadiyahan.

Dari hasil pembahasan dan data lapangan penyelenggaraan mata kuliah AIK pada semester III program studi Akuntansi FEB UMT. Telah diperoleh impementasi sikap kesalehan spiritual dan sosial saat diselenggarakannya mata kuliah Al Islam dan Kemuhammadiyahan. Sebagaimana dalam penyusunan kurikulum yang telah disepakati pimpinan LPK AIKA Universitas Muhammadiyah Tangerang sebagai Lembaga yang diberikan wewenang oleh Rektorat untuk memfasilitasi seluruh aktivitas pembelajaran AIK pada seluruh program studi, maka pada jenjang semester III yang menjadi materi pokok mata kuliah AIK adalah penananman Ideologi Muhammadiyah, dalam hal ini memahami dan menghayati napaktilas sejarah perjuangan Muhammadiyah yang pertama kali didirikan oleh KH. Ahmad Dahlan, serta mahasiswa diberikan tugas oleh Dosen untuk melakukan dakwah lapangan memberikan kepedulian kepada sesamanya masyarakat yang ada dilingkungannya masing-masing, dengan maksud agar mahasiswa benar-benar mengerti maksud dan tujuan dari mata kuliah AIK ini yakni memahami kiprah persyarikatan Muhammadiyah dalam menyampaikan dakwah kepada masyarakat yang dilatarbelakangi pada Al-Qur'an Surat AlMaun ayat 1-7. Sebagaimana Allah Swt berfirman:

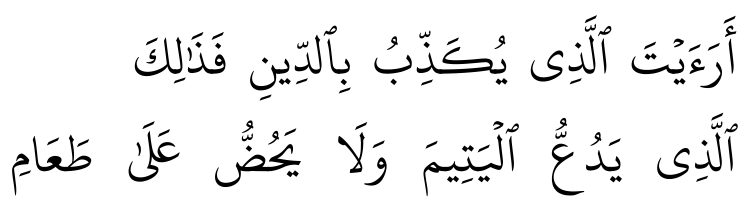




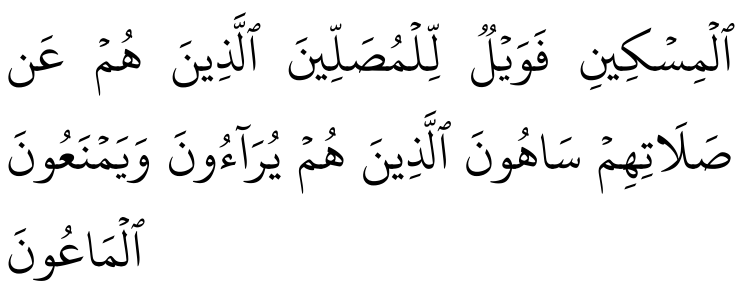

"Tahukah kamu (orang) yang mendustakan agama?, Itulah orang yang menghardik anak yatim, dan tidak menganjurkan memberi makan orang miskin. Maka kecelakaanlah bagi orangorang yang shalat, (yaitu) orang-orang yang lalai dari shalatnya, orang-orang yang berbuat riya, dan enggan (menolong dengan) barang berguna."

Berdasarkan ayat di atas $\mathrm{KH}$. Ahmad Dahlan mentafsirkan Al-Maun dalam kegiatan utama yaitu: Pendidikan, kesehatan, dan menyantuni fakir miskin yang merupakan transformasi pemahaman keagamaan, dalam konteks inilah teologi Islam menjadi sangat concern pada usaha mengentaskan masalah kemiskinan sebagai manifestasi ta'awun 'ala al-birri wa taqwa. Pedoman utamanya adalah konsep tauhid yang menuntut ditegakkannya keadilan sosial, karena jika dilihat dari perspektif tauhid setiap gejala eksploitasi manusia merupakan pengingkaran terhadap persamaan derajat manusia di hadapan Allah Swt, maka jurang menganga lebar antara lapisan kaya dan lapisan miskin yang selalu disertai kehidupan yang eksploitatif merupakan fenomena yang tidak bertauhid melainkan anti tauhid (Kemuhammadiyahan, 2018).

Metodologi penafsiran yang digunakan KH. Ahmad Dahlan pada QS. Al-Maun ataupun surat-surat yang lainnya tidak berdasarkan pemahaman normatif tekstual semata, melainkan keluar dari mainstream pemikiran demi mencapai tujuan dakwah Islam yang beliau citacitakan dalam bentuk tafsir aksi atau praksis sosial.

KH. Ahmad Dahlan memiliki pemahaman teologis yang komprehensif, tidak hanya dalam akal pikirannya melainkan paham teologi yang harus dipraksiskan dalam amal nyata sesuai kebutuhan dan kemaslahatan umat. Kondisi ini bisa dimengerti karena Kiyai seorang priyai Jawa memiliki sifat dan sikap (etos) welas asih sebagai kultur dari etika Jawa. dr. Soetomo seorang dokter priyai tertarik dan terlibat aktif dalam Muhammadiyah karena melihat welas asihnya KH. Ahmad Dahlan disampaikannya dalam sambutan pembukaan rumah sakit PKU Muhammadiyah Surabaya di tahun 1924.

Selanjutnya, semangat menolong kesengsaraan umum menjadi salah satu ruh dakwah Muhammadiyah dari waktu ke waktu. Menurut Haedar Nashir, menegaskan dari semangat tersebut, lahirlah rumah sakit, poliklinik, panti asuhan, rumah miskin, rumah yatim, dan berbagai kegiatan pemberdayaan masyarakat

(https://www.republika.co.id/berita/nasiona 1/sang-pencerah/17/05/10/oppt1e368-

pemberdayaan-dhuafa-jadi-fokus-gerakanmuhammadiyah).

Teologi Al-Maun memiliki beberapa prinsip. Pertama, Islam sebagai agama amal yang menjunjung tinggi perbuatan baik sebagai bagian dari iman. Kedua, Islam agama pembebasan yang mengangkat kaum lemah dari penindasan. Ketiga, Islam agama praksis, yakni aksi yang bersifat humanisasi dan emansipasi, lalu membawa orang lemah menjadi berdaya dan maju. Persyarikatan Muhammadiyah senantiasa bersemangat dalam menolong kesengsaraan umum teraplikasi dalam lima gerakan yang diantaranya melalui amal usaha kesehatan, pelayanan sosial, gerakan pemberdayaan masyarakat, penanggulangan bencana, serta gerakan lembaga amil zakat infak sedekah (lazis) untuk memobilisasi dana umat. Semua gerakan itu, menurut Haedar, diarahkan pada program-program lapangan agar orang-orang lemah tidak sekadar disantuni. Tapi mereka bisa menjadi orangorang yang berdaya, mandiri, dan memiliki kemampuan usaha (https://www.republika.co.id/berita/nasiona 1/sang-pencerah/17/05/10/oppt1e368pemberdayaan-dhuafa-jadi-fokus-gerakanmuhammadiyah).

Muhammadiyah sebagai gerakan dakwah amar ma'ruf nahi munkar 
bertanggung jawab ambil bagian dalam penyelesaian masalah tersebut dengan menjabarkan tafsir surat al-Maun ke dalam keyakinan teologis dan amal (praksis) sosial. Secara umum Munas Tarjih ke-27 menyepakati bahwa sistematika Fikih al Maun ada dalam "Kerangka Amal alMa'un" yang berupa penguatan dan pemberdayaan kekayaan fisik, moral, spiritual, ekonomi, sosial dan lingkungan. Kemudian "Pilar Amal al-Ma'un" terdiri dari rangkaian berkhidmat kepada yang yatim, berkhitmat kepada yang miskin, mewujudkan nilai-nilai shalat, memurnikan niat, menjauhi riya', dan membangun kemitraan yang berdayaguna. Sementara "Bangunan Amal al-Ma'un" yang disepakati adalah untuk kesejahteraan individu yang bermartabat, kesejahteraan keluarga (Keluarga Sakinah), kesejahteraan masyarakat yang berjiwa besar, kesejahteraan bangsa dan negara.

Dengan demikian, pemahaman tentang Tafsir Surat al-Maun, Teologi alMaun ataupun Fikih al-Maun di atas tidak boleh berhenti hanya pada konsepsi pemikiran belaka, melainkan harus dapat dijabarkan dalam realisasi amal sosial yang terus dikembangkan sesuai dengan kebutuhan umat dan perkembangan zamannya. Dengan begitu, baik penafsiran ayat Al-Qur'an, penghayatannya dalam hati sebagai keyakinan hidup (teologi) maupun pengamalannya dalam kehidupan sehari-hari (fikih) sesuai dengan pemikiran KH. Ahmad Dahlan yang menekankan "siapa menanam akan mengetam", dan "pemimpin itu sedikit bicara banyak bekerja" (Gunawan, 2018).

Dari uraian di atas jelas bahwa kepentingan mata kuliah AIK di semester III program studi Akuntansi FEB UMT adalah untuk mengejawantahkan nilai dan pesan moral yang terkandung pada AlQur'an Surat Al-Maun yang disenergikan dengan gerak dakwah praksis Muhammadiyah. Kemudian, mata kuliah AIK sebagai bagian integral kurikulum relevan untuk diterapkan dalam pengintegrasian karakter atau nilai-nilai ke dalam kegiatan pembelajaran setiap mata kuliah yang tertera dalam kurikulum AIK.
Atas pertimbangan tersebut, maka mata kuliah AIK dalam mewujudkan implementasi sikap kesalehan spiritual dan sosial tidak merupakan perkuliahan yang berdiri sendiri, tetapi diintegrasikan dalam kurikulum dan berfungsi menjadi penguat kurikulum yang sudah ada. Pengintegrasian nilai-nilai kesalehan spiritual dan sosial ke dalam kegiatan pembelajaran berarti memadukan, memasukkan, dan menerapkan nilai-nilai yang diyakini baik dan benar dalam rangka membentuk, mengembangkan, dan membina tabiat atau karakter mahasiswa sesuai jati diri bangsa tatkala kegiatan pembelajaran berlangsung. Materi pembelajaran yang berkaitan dengan norma atau nilai pada setiap pelajaran perlu dikembangkan, diekplisitkan, dikaitkan dengan konteks kehidupan sehari-hari (Baidrus et.al, 2019).

Dengan demikian, perkuliahan AIK nilai-nilai kesalehan spiritual dan sosial tidak hanya pada tataran kognitif tetapi menyentuh pada pengalaman nyata dalam kehidupan mahasiswa sehari-hari dimasyarakat. Setiap dosen diharapkan dapat menjadi teladan pada implementasi sikap kesalehan spiritual dan sosial dan setiap dosen AIK seharusnya berkompeten untuk membimbing sifat dan sikap para mahasiswanya, artinya setiap dosen mata kuliah AIK sudah sepatutnya memiliki tugas dan tanggung jawab untuk mengarahkan sikap Islami kepada mahasiswa yang diampunya.

Mahasiswa semester III program studi Akuntansi FEB UMT telah berhasil dan mampu mengimplementasikan sikap kesalehan spiritual dan sosial. Hal ini dikarenakan pada mata kuliah AIK tidak sekedar memberikan teori tentang kemuhammadiyahan tetapi mahasiswa juga langsung turun ke jalan mengobservasi keadaan masyarakat yang tidak mampun yang selanjutnya di santuni dan diberikan pemahaman nilai-nilai agama Islam sebagaimana pembelajaran yang disampaikan selama mata kuliah AIK berlangsung. Oleh karena itu, menyampaikan spirit Muhammadiyah kepada para mahasiswa diharapkan untuk 
memilih di antara beberapa pendekatan dari dimensi kehadiran dan kontribusi Muhammadiyah hal ini bertujuan agar mahasiswa dapat memahami model perjuangan yang selama ini dilakukan oleh persyarikatan Muhammadiyah. Mata kuliah ini hendak memperkenalkan melalui salah satu di antara nilai-nilai dan tradisi yang berkembang sangat kuat dalam tubuh Muhammadiyah. Di samping nilai-nilai keikhlasan dalam berdakwah, kesederhanaan, etos keilmuan, maka kedermawanan merupakan salah satu nilai yang berkembang kuat dan menjadi nilai utama yang menggerakkan jamaah Muhammadiyah di seluruh Indonesia.

Pada masa berdirinya persyarikatan Muhammadiyah, KH. Ahmad Dahlan telah berhasil mempraktekkan nilai kehidupan yang luhur bahwa "hidup itu untuk memberi". Dibangun di atas landasan teologi sosial surat Al-Maun, KH. Ahmad Dahlan dalam memberikan pelajaran kepada murid-muridnya bahwa berislam itu tidak hanya sekedar paham dan mengerti tentang Islam, tetapi yang terpenting adalah sampai kepada kemampuan "memberi" untuk membangun praktek hidup yang Islami. Bahwa bukti dari sikap beragama yang lurus dan benar itu adalah diindikasikan oleh kepedulian terhadap sesama terutama yang tertindas dan yang terpinggirkan.

Nilai kedermawanan inilah yang menjadi basis strategis bagi mata kuliah AIK pada semester III program studi Akuntansi FEB UMT untuk menanamkan nilai perjuangan Muhammadiyah, tidak sekedar berceramah tentang cerita-cerita dan sejarah kedermawanan dalam Muhammadiyah, tetapi mahasiswa dikondisikan untuk mengalami secara terstruktur pengalaman implementasi sikap kesalehan spiritual dan sosial di lapangan. Melalui mata kuliah ini mahasiswa diminta untuk mencari dan menemukan keluarga dhuafa dengan pendekatan akademik, membangun hubungan yang cukup dalam dengan keluarga-keluarga dhuafa, menidentifikasi masalah mereka, merencanakan strategi pemberdayaan untuk mereka, menggerakkan dan memberdayakan keluarga dhuafa untuk mengalami transformasi ke arah kemandirian dan perbaikan kualitas kehidupan. Di sisi yang lain, mahasiswa melalui mata kuliah ini juga membangun hubungan dengan keluarga-keluarga agniya dan menjadi calon donatur dan Lembaga-lembaga ekonomi, sosial, dan pemerintahan yang potensial menjadi calon donatur dan membantu dan mensukseskan kegiatan pemberdayaan keluarga dhuafa. Sederhananya, mahasiswa mengalami untuk menjadi Amil, peran yang menjembatani keluarga dhuafa dengan para agniya. Mahasiswa mendatangi kedua kelompok sosial-ekonomi tersebut untuk dapat belajar tentang hidup dan dalam waktu yang bersamaan mahasiswapun belajar tentang Muhammadiyah.

Namun, sebelum mahasiswa menunaikan penugasan pemberdayaan keluarga dhuafa dalam rangka mengimplementasikan sikap kesalehan spiritual dan sosial pada mata kuliah AIK, mahasiswa diberikan pembekalan terlebih dahulu oleh Dosen mata kuliah AIK. Alur perkuliahan mata kuliah AIK disusun secara bertahap, tetapi saling berkaitan antara satu dan lainnya yaitu, a. pengantar perkuliahan AIK, b. Pembekalan teologis dan teoritik, c. pembekalan teknis dan pelaksanaan dakwah lapangan, d. ceramah dan diskusi, e. presentasi laporan hasil pemberdayaan, dan f. ceramah dan dikusi.

Secara rinci dari perkuliahan AIK dapat dilihat pada jadwal perkuliahan sebagaimana berikut:

Tabel 1 Jadwal Mata Kuliah AIK

\begin{tabular}{|c|l|c|}
\hline $\begin{array}{c}\text { Minggu } \\
\text { Ke }\end{array}$ & \multicolumn{1}{|c|}{ Bahan Kajian } & Tanggal \\
\hline I & $\begin{array}{l}\text { Pengantar } \\
\text { Perkuliahan }\end{array}$ & \\
\hline II & $\begin{array}{l}\text { Makna surat Al- } \\
\text { Maun secara teologis } \\
\text { dan praksis sosialnya } \\
\text { (Hapalan surat Ali } \\
\text { Imran 104 dan Al- } \\
\text { Maun 1-7 beserta } \\
\text { terjemahannya) }\end{array}$ & \\
\hline
\end{tabular}




\begin{tabular}{|c|c|}
\hline III & $\begin{array}{l}\text { Dakwah pencerahan } \\
\text { dan tanggungjawab } \\
\text { membangun keluarga } \\
\text { Indonesia } \\
\text { berkemajuan }\end{array}$ \\
\hline IV & $\begin{array}{l}\text { Strategi dan } \\
\text { implementasi } \\
\text { menemukan keluarga } \\
\text { dhuafa sesuai dengan } \\
\text { indicator yang } \\
\text { dikembangkan }\end{array}$ \\
\hline $\mathrm{V}$ & $\begin{array}{l}\text { Proposal untuk } \\
\text { pemberdayaan } \\
\text { keluarga dhuafa }\end{array}$ \\
\hline VI & $\begin{array}{l}\text { Menghimpun dana } \\
\text { untuk pemberdayaan } \\
\text { keluarga dhuafa }\end{array}$ \\
\hline VII & $\begin{array}{l}\text { Penyaluran bantuan } \\
\text { pemberdayaan untuk } \\
\text { keluarga dhuafa }\end{array}$ \\
\hline VIII & UTS \\
\hline IX & $\begin{array}{l}\text { Konsep Islam } \\
\text { berkemajuan untuk } \\
\text { membangun } \\
\text { Indonesia } \\
\text { berkemajuan }\end{array}$ \\
\hline $\mathrm{X}$ & $\begin{array}{l}\text { Ideologi } \\
\text { Muhammadiyah }\end{array}$ \\
\hline XI & $\begin{array}{l}\text { Tiga pilar dakwah } \\
\text { Muhammadiyah: } \\
\text { Pendidikan, } \\
\text { kesehatan, dan } \\
\text { ekonomi }\end{array}$ \\
\hline XII & $\begin{array}{l}\text { Presentasi dakwah } \\
\text { pemberdayaan } \\
\text { keluarga dhuafa }\end{array}$ \\
\hline XIII & $\begin{array}{l}\text { Presentasi dakwah } \\
\text { pemberdayaan } \\
\text { keluarga dhuafa }\end{array}$ \\
\hline XIV & $\begin{array}{l}\text { Presentasi dakwah } \\
\text { pemberdayaan } \\
\text { keluarga dhuafa }\end{array}$ \\
\hline $\mathrm{XV}$ & $\begin{array}{l}\text { Perjalanan sejarah } \\
\text { Muhammadiyah } \\
\text { selama } 1 \text { abad lebih }\end{array}$ \\
\hline XVI & UAS \\
\hline
\end{tabular}

Berdasarkan jadwal kuliah di atas, maka mata kuliah AIK memiliki tujuan: Pertama, mahasiswa dapat belajar tentang hidup dari dunia nyata yang dialami oleh keluarga dhuafa. Kedua, mehasiswa memiliki pengalaman dalam mendesain dakwah dengan pendekatan pemberdayaan yang sistematis, programatis, tetapi juga beradab, dan mengedepankan marwah ajaran Islam. Ketiga, mahasiswa memahmi kiprah dakwah Muhammadiyah berdasarkan refleksi atas pengalaman mereka sendiri yang didialogkan dengan pengalaman satu abad lebih gerak Muhammadiyah mempengaruhi Indonesia hingga saat ini. Keempat, mahasiswa mampu memberdayakan keluarga dhuafa. sedangkan pencapaian yang diinginkan dari mata kuliah AIK adalah Pertama, mahasiswa mampu menerapkan model dakwah pencerahan untuk keluarga dhuafa. Kedua, mahasiswa mampu memahami dimensi-dimensi dan hasil gerakan Muhammadiyah. Ketiga, mahasiswa mampu menginternalisasikan nilai-nilai dasar muslim berkemajuan.

Adapun, untuk mencapai tujuan dan pencapaian mata kuliah di atas maka hendaknya dikelola dengan model pembelajaran experiental learning. Sebuah model pembelajaran yang diidentifikasikan sebagai "proses bagaimana pengetahuan diciptakan melalui perubahan bentuk pengalaman. Pengetahuan diakibatkan oleh kombinasi pemahaman dan mentransformasikan pengalaman. Melalui model pembelajaran experiental learning, mahasiswa didorong untuk belajar dan mengkonstruksikan pemahaman tentang dakwah pemberdayaan keluarga dhuafa dari pengalaman berkomunikasi dan berinteraksi dengan keluarga dhuafa tersebut, dengan begitu dalam waktu yang bersamaan mahasiswa akan mampu mengimplementasikan sikap kesalehan spiritual dan sosial, dengan demikian terjadi perubahan struktur kognitif, sikap dan keterampilan mahasiswa terkait dengan pendekatan dakwah yang efektif dan bermartabat.

Berdasarkan

pelaksanaan perkuliahan yang telah dilakukan oleh mahasiswa dalam rangka menunaikan pemberdayaan keluarga dhuafa mata kuliah AIK III semester Ganjil Tahun 
Akademik 2020/2021 serta merujuk pada perangkat pembelajaran. Maka pada implementasi sikap keshalehan spiritual dan sosial yang dapat di uraikan adalah sebai berikut:

Pertama, membaca dan menghapal Al-Qur'an Surat Al-Maun sebagai pemantapan spiritual kepada Allah Swt. Mahasiswa dibimbing untuk membaca serta menghapal surat Al-Maun dengan terjemahannya. Dengan jangka waktu yang diberikan oleh dosen AIK selama satu pekan, adapun hasilnya mahasiswa berhasil menghapalnya dengan baik berikut dengan terjemahannya. Andiya Fajarini mengungkapkan bahwa pentingnya menghafal menghafal Al-Qur'an seharusnya bisa menjadi fokus utama yang tidak kalah penting untuk dilakukan oleh para peserta didik. Qardhawi dalam Andiya Fajarini menjelaskan bahwa ilmu yang dianjurkan oleh Islam untuk dipelajari dan ditunjukkan oleh Al-Qur'an untuk digali adalah setiap ilmu pengetahuan yang didasari oleh dalil-dalil.

Menghafal, selain sebagai jalan untuk memperoleh kepahaman terhadap suatu materi pelajaran, juga berfungsi sebagai jalan untuk meningkatkan budaya membaca dikalangan mahasiswa. Berbicara tentang menghafal, berarti berbicara pula tentang belajar dan setiap aktivitas yang berhubungan dengan-Nya melantunkan ayat-ayat yang penuh dengan hikmah, seperti membaca, menulis, dan termasuk didalamnya aktivitas kognitif lainnya. Dalam hubungan soal mencamkan (menerima kesankesan) yang menjadi salah satu aspek dalam berfungsinya ingatan, terdapat satu hal penting yang menjadi sebab istimewanya kedudukan individu yang menjalani aktivitas menghafal, yaitu interferensi. Interferensi yang dimaksud adalah menjadi lebih sukarnya proses belajar yang disebabkan oleh hambatan bahan-bahan yang telah dipelajari lebih dulu.

Kedua, menumbuhkan semangat mengamalkan Al-Quran kepada mahasiswa dalam kehidupan sehari-hari sebagai bentuk ibadah kepada Allah Swt. Mahasiswa yang telah menghapal berikut dengan terjemahannya surat Al-Maun, diharapkan dapat menggugah hati dan perbuatannya untuk senantiasa mengamalkan nilai-nilai tersebut sebagai bentuk ibadah kepada Allah. Pengertian ibadah disini tentunya tidak dipahami secara sempit, tetapi dipahami secara luas. Ibadah kepada Allah Swt Diungkapkan oleh Andi Gunawan bahwa KH. Ahmad Dahlan dalam menyampaikan pokok pikiran dan ajarannya salah satunya dengan menggunakan model pembelajaran Alquran. KH. Ahmad Dahlan menggunakan metode lima jalan dalam memahami Alquran, yaitu: 1). Memehami artinya; 2). Memahami tafsir dan maksudnya; 3). Jika mendapatkan larangan dalam Alquran bertanyalah kepada diri sendiri, apakah larangan tersebut sudah ditinggalkan; 4). Jika mendapat amar atau perintah perbuatan dalam Alquran bertanyalah kepada diri sendiri, apakah amar atau perintah tersebut sudah diamalkan; 5). Jika amar atau perintah tersebut belum diamalkan jangan membaca ayat yang lain.

Ketiga, menumbuhkan sikap dermawan dan kepedulian sosial. Setelah mahasiswa diarahkan dalam perkuliahan untuk dapat memahami nilai yang terkandung dalam surat Al-Maun, teknis observasi masyarakat dhuafa, pembuatan proposal perencanaan penganggaran bantuan kepada dhuafa, penggalangan dana, sampai ke penyaluran bantuan yang sebelumnya telah direncanakan dalam program bantuan kaum dhuafa. Maka dalam waktu yang bersamaan mahasiswa akan muncul rasa empati kepada keluarga dhuafa yang sudah di observasi sebelumnya, mahasiswa akan berjuang membantu mereka guna mengimplementasikan ajaran Islam yang ada pada surat Al-Maun tersebut.

Dari hasil akumulasi penggalangan dana yang dilakukan oleh mahasiswa program studi Akuntansi semester III kelas 3 Shif 1 dan 3 Shif 3 FEB UMT pada Tahun Akademik 2020-2021 berhasil menghimpun dana sebesar Rp. 30.167.000,- . dari dana tersebut telah 
berhasil disalurkan kepada kaum dhuafa di wilayah Tangerang dan sekitarnya

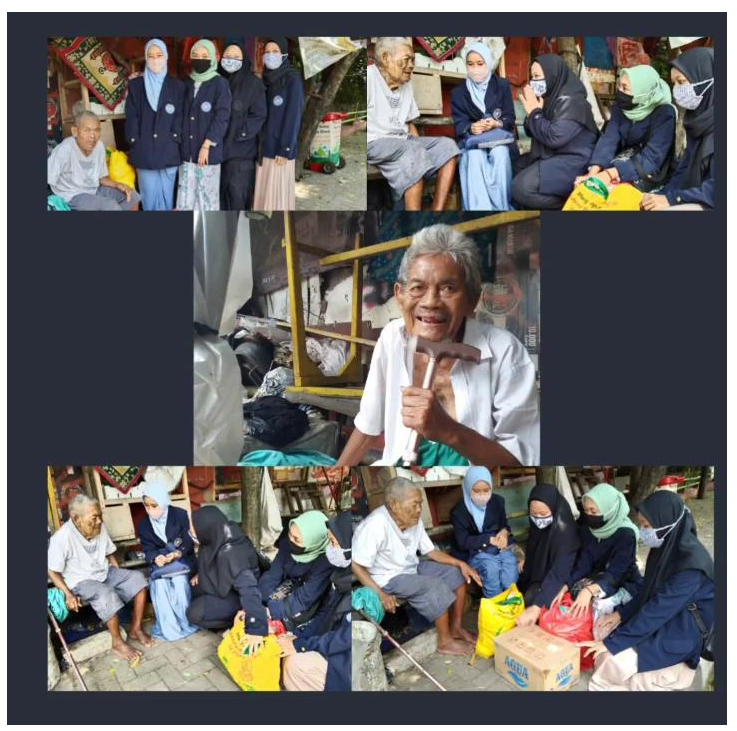

Gambar 1 Dokumentasi Penyerahan Bantuan Keluarga Dhuafa

Selain sebagai bentuk pemenuhan nilai mahasiswa pada mata kuliah Al-Islam dan kemuhammadiyahan. Kegiatan ini diharapkan dapat terus dilakukan oleh mahasiswa dalam kesempatan yang berbeda dimana saja dan kapan saja. Kemudian, sebagaimana yang telah dilakukan oleh KH.Ahmad Dahlan memberikan keteladanan untuk menjadi muslim yang autentik atau seutuhnya pada masa awal persyarikan Muhammadiyah didirikan. Berislam belum cukup hanya dipahami dan diyakini, tetapi harus diresapi dengan amal perbuatan dan dipraktekkan, sikap kedermawanan dan peduli sosial sudah sangat melekat pada organisasi yang didirkan oleh KH.Ahmad Dahlan, hal ini terbukti dengan amal usaha yang dimiliki oleh persyarikatan Muhammadiyah yang tersebar diseluruh Indonesia mulai dari Lembaga Pendidikan, ekonomi, dan sosial.

\section{KESIMPULAN}

Berdasarkan pembehasan di atas terkait dengan implementasi sikap kesalehan spiritual dan sosial dalam mata kuliah Al-Islam dan Kemuhammadiyahan. Maka dapat disimpulkan bahwa mata AIK merupakan pembelajaran yang wajib disampaikan kepada mahasiswa mulai dari semester I sampai dengan $\mathrm{V}$. dengan mata kuliah ini setiap perguruan tinggi Muhammadiyah menjadikan mata kuliah tersebut sebagai langkah strategis menyampaikan pendidika Islam kepada para mahasiswa berdasarkan sumber ajaran Islam Al-Quran dan As-Sunnah. Selanjutnya berdasarkan analisis yang telah dilakukan pada mata kuliah AIK pada semester III terdapat indikasi impelementasi sikap kesalehan spiritual dan sosial diantaranya yaitu, Membaca dan menghapal Al-Qur'an Surat Al-Maun sebagai pemantapan spiritual kepada Allah Swt, Menumbuhkan semangat mengamalkan Al-Quran dalam kehidupan sehari-hari sebagai bentuk ibadah kepada Allah Swt, dan menumbuhkan sikap dermawan dan kepedulian sosial.

\section{DAFTAR PUSTAKA}

Abdillah S, Milana, Agus Salim, 2020. "Evaluasi Pembelajaran Mata Kuliah Al-Islam dan Kemuhammadiyahan sebagai Internalisasi Penguatan Pendidikan Karakter Mahasiswa Prodi PAI di Universitas Muhammadiyah Tangerang", Jurnal Tadarus Tarbawy, Vol. 2 No. 1.

Baidrus. Dkk, 2019. "Al-Islam dan Kemuhammadiyahan sebagai Basis Pendidikan Karakter", Jurnal: Journal Basic Of Education, Vol.4, No.1.

Fajarini, Andiya, 2017. "Model Menghafal pada Penghafal Al-Qur'an Implikasinya pada Layanan Penguasaan Konten dalam Bimbingan dan Konseling”, Jurnal Bimbingan Konseling UNNES Vol. 6 No.1.

Gunawan Andri, 2018. "Teologi Surat AlMaun dan Praksis Sosial dalam Kehidupan Warga Muhammadiyah", Jurnal Salam: Jurnal Sosial dan Budaya Syar-I, Vol. 5 No. 2.

Hawi, Akmal, 2013. Kompetensi Guru Pendidikan Agama Islam, Jakarta: PT. RajaGrafindo Persada. 
Majelis Dikti PP Muhammadiyah, 2013. Pedoman Pendidikan AIK, Yogyakarta: Majelis Dikti PP Muhammadiyah.

Misran, Syamsu S. 2019. "Manajemen Kurikulum Pendidikan Al-Islam dan Kemuhammadiyahan", Kelola: Journal of Islamic Education Management, Vol. 4 No.2 Oktober.

Nasir, Haedar, 2021. "Pemberdayaan Dhuafa Jadi Fokus Gerakan Muhammadiyah", diakses dari https://www.republika.co.id/berita/ nasional/sang-

pencerah/17/05/10/oppt1e368-

pemberdayaan-dhuafa-jadi-fokusgerakan-muhammadiyah.

Rusmin B, Muhammad, 2017. "Konsep dan Tujuan Pendidikan Islam", Jurnal Fakultas Tarbiyah dan Keguruan UIN Alauddin Makasar, Vol. VI No.1.

Tim Penulis Dosen AIK PTM SeJabodetabek, 2018. Kemuhammadiyahan, Yogyakarta: Suara Muhammadiyah. 